ISSN 1676-3742

\title{
A Centralidade do episcopado no Concílio Vaticano II Aspectos teológicos e as retomadas pastorais
}

\author{
The Centrality of the Episcopate in \\ the Second Vatican Council \\ Theological aspects and the pastoral implications
}

Dom Filippo Santoro

\section{Resumo}

O ponto de partida é a profissão de fé na Igreja Apostólica, com a identidade de seus princípios de unidade na Tradição viva. Destaca-se, então, a experiência do Concílio Vaticano II. Faz-se primeiramente uma contraposição com a orientação teológica anterior, desde a teologia medieval às vésperas do concílio; esta via o episcopado como ampliação do ministério sacerdotal. Já o Vaticano II entende o episcopado como plenitude do ministério, com o tríplice múnus: sacerdote, mestre e pastor. $\mathrm{O}$ artigo desenvolve uma abordagem analítica da contribuição do concílio, tomando especialmente trechos da constituição Lumen Gentium e do decreto Christus Dominus. Discorre sobre a sacramentalidade do episcopado, a colegialidade episcopal e a ministerialidade episcopal, com uma visão diaconal do ministério. Na conclusão, considera a presidência eclesial e acentua três dimensões dadas no ministério episcopal: a memorial/pascal; a santificante/escatológica e a testemunhal/martirológica.

Palavras-chave: Episcopado; sacramentalidade; colegialidade; ministério. 


\begin{abstract}
The starting point is the profession of faith in the apostolic Church with the identity of its principles of unity in the living Tradition. It accentuates, therefore, the experience of the Second Vatican Council. It first makes a counterpoint with the previous theological orientation, from medieval theology until the eve of the Council; this viewed the episcopate as the amplification of priestly ministry. However Vatican II understood the episcopate as the fullness of the ministry, with the triple function: priest, teacher and shepherd. The article develops an analytical approach to the contribution of the Council, especially using passages of the constitution Lumen Gentium and from the decree Christus Dominus. It touches on the sacramentality of the episcopate, episcopal collegiality and episcopal ministry, with a diaconal vision of the ministry. In conclusion, it considers, the episcopal presidency and accentuates three dimensions given in the episcopal ministry: the memorial/paschal, the sanctifying/eschatological and the witnessing/ martyrological.
\end{abstract}

Keywords: Episcopate; sacramentality; collegiality; ministry.

\title{
Introdução
}

No Credo, professamos a Igreja "apostólica". Esta verdade dogmática exprime bem o proprium da santa assembléia, do povo reunido em nome do Senhor. A "Apostolicidade" é a propriedade graças à qual a Igreja conserva, através do tempo, a identidade de seus princípios de unidade, tais como recebeu do Cristo, na pessoa dos apóstolos, isto é, daqueles que encontramos indicados em Mt 28, 19-20 e At 2, $42 .{ }^{1}$

Toda reflexão teológica séria não pode nunca prescindir do dado escriturístico e magisterial, da Tradição viva da Igreja. O delicado e vinculante tema que aqui abordamos tem seu fundamento na experiência viva de fé que a Igreja viveu com e no Vaticano II, onde a hermenêutica da reforma de quanto foi desenvolvido naquela tribuna aparece ainda mais atual. Falar de episcopado e da sua centralidade na experiência conciliar quer dizer várias coisas. Primeiramente, refere-se ao valor da presença de tantos bispos para aquele momento forte da vida e da história da Igreja: nunca tantos bispos reunidos

${ }^{1}$ CONGAR, Y. “La Chiesa è Apostolica”. In Mysterium Salutis VII, Brescia: Queriniana, 1972, 639. 
juntos em um concílio, de caráter e sabor realmente "católico". Não de menos, penso também na reflexão desenvolvida pelas várias "escolas teológicas" que faziam referência aos vários episcopados; pensemos no francófono e no alemão, no estadunidense e no mundo latino-americano, no "romano ou italiano", na realidade dos países em via de desenvolvimento, até o mundo oriental com tantos irmãos bispos de outros ritos. O tema do episcopado pode ser também afrontado transversalmente aos vários documentos produzidos pelo concílio, evidenciando a peculiaridade e a afinidade. Interessante é também o relacionamento bispos-papa, mas isto foi objeto de outro artigo. O corte que este artigo terá, ao contrário, será analítico, ou seja, a atenção será dirigida para alguns textos-chave da Lumen Gentium e em parte do Christus Dominus para acentuar alguns dados originais e próprios do aporte que a reflexão teológica e o magistério nos entregaram com o Concílio. Os temas aqui apresentados serão, pois, a sacramentalidade do episcopado, a colegialidade episcopal e a ministerialidade episcopal, ou seja, a visão diaconal do ministério.

\section{Alguns pressupostos teológicos}

O Vaticano II realizou uma virada copernicana a respeito da tradição medieval que tinha influenciado a teologia e o magistério até a vigília (ou quase) do Concílio sobre a concepção mesma do episcopado. ${ }^{2}$ A teologia medieval via o ministério em função da eucaristia, único centro vinculante da vida da Igreja; e o ministério episcopal era compreendido como ampliação do ministério sacerdotal, uma dignidade superior, atuando uma distinção e separação entre ordo e iurisdictio, entre potestas ordinis, em referência à dimensão sacramental, e o poder ligado ao ofício e, portanto, dependente da canônica determinatio. O Concílio, ao invés, nos entregou uma visão de episcopado como plenitude do ministério, vendo no ministério sacerdotal uma participação gradual nesta única ordo (cf. LG 21). Com a ordenação episcopal, é transmitido ao bispo o tríplice munus (sacerdote, mestre e pastor), dando um primado ao sacramento sobre a determinação canônica que no passado era vista, não só como conditio para o lícito exercício do ministério episcopal, mas a fonte mesma para seu exercício. Já na reflexão teológica antes e durante o concílio esta nova visão sacramental do episcopado emergiu, graças à contri-

\footnotetext{
${ }^{2}$ Cf. PIÉ-NINOT, S. Ecclesiologia. La sacramentalità della comunità Cristiana, BTC 138, Brescia: Queriniana, 2008, 391ss. KASPER, W. Chiesa Cattolica. Essenza-Realtà-Missione, BTC 157, Brescia: Queriniana, 2012, 369ss.
} 
buição determinante de Congar que, precisamente naqueles anos, publicara textos-chaves. ${ }^{3}$

Para compreender melhor a questão, convém deter-se primeiramente sobre a estrutura do capítulo III da Lumen Gentium; assim ela ficará mais clara. Logo, podemos encontrar dois minitratados e dois complementos ou corolários deles. O primeiro tratado é "sobre o episcopado como sujeito colegial" (LG 18-21); o segundo, sobre o "bispo e seu ministério" (LG 24-27); os dois complementos ou corolários são seus "presbíteros" (LG 28) e seus “diáconos” (LG 29).

Os temas próprios destes números são:

18: Prô̂mio

19: Vocação e instituição dos doze

20: Os sucessores dos apóstolos

21: Sacramentalidade

do episcopado

22: O colégio episcopal e seu chefe

23: Relações dos bispos no colégio

24: O ministério dos bispos
25: A função de ensinar

26: A função de santificar

27: A função de governar

28: Os presbiteros em relação a Cristo, aos bispos, ao presbitérioe aos fiéis

29. Os diáconos

Do esquema emerge a natureza mesma do "tratado" sobre o episcopado que o concílio quis entregar, de onde se extrai logo a referência da continuidade Cristo-apóstolos e sucessores e em paralelo a compreensão do ministério de todo bispo. O parágrafo 18 inicia "Christus Dominus ad Populum Dei pascendum semperque augendum, in Ecclesia sua varia ministeria instituit, quae ad bonum totius Corporis tendunt". Em continuidade com a Pastor Aeternus do Vaticano II, compara Cristo como verdadeiro pastor do povo de Deus que, para apascentar e aumentar sua grei, institui uma pluralidade de ministérios. Então, o dado cristológico da instituição, o motivo (nutrir e aumentar), e, por último, a pluralidade na unidade ministerial revelam como de repente os padres conciliares quiseram evidenciar o relacionamento um-muitos, unidade e colegialidade. Neste quadro de referência,

\footnotetext{
${ }^{3}$ Cf. CONGAR, Y. M. L'Episcopat e l'Eglise universelle. Paris: Cerf, 1962; Id., La collégialité épiscopale, Paris: Cerf, 1963.
} 
compreendemos bem como o Concílio, ao apresentar a natureza e a missão do episcopado, distingue a realidade sacramental-colegial daquela funcional-ministerial. Em outras palavras, o Concílio entende pôr as bases de uma teologia do episcopado que até então estava escondida por uma perspectiva que tinha acentuado o papel primacial do papa e ocultado o dos bispos, considerados mais pessoalmente em suas igrejas locais que enquanto colégio. Com efeito, o dado magisterial precedente ao Vaticano II, e especialmente o Vaticano I, foi muitas vezes eivado por interpretações "papalistas", conduzidas por certas correntes também anteriores a 1870 , talvez motivadas pelo santo zelo da comunhão eclesial. Estas consideravam a crise do nascimento dos estados nacionais com motivações centrífugas - pensemos no conciliarismo e depois no galicanismo- mas também na perda do papel "sócio-político" do papado e a reapropriação de sua identidade no cenário público - aspectos típicos dos anos 800 italiano e europeu. O concílio ensina, ao contrário, que o bispo não se concebe mais sem um colégio episcopal, em cujo coração está o bispo de Roma, mas ao mesmo tempo não existe um papel de bispo senão retomando aqueles três múnus que a Lumen Gentium primeiramente, (mas também outros documentos cum um corte marcadamente "pastoral": Presbiterorum Ordinis, Christus Dominus, Apostolicam Actuositatem), aplica a todas as categorias de membros da Igreja, a começar dos bispos, depois os presbíteros e leigos. Nesta visão também o ministério "sacerdotal", o "presbiterado" é apresentado em chave colegial e não individual (fala-se de "presbíteros" no plural), mas evitando as acentuações sacralizantes do ministério; depois passando de uma visão "cultual" a uma "ministerial"; de uma visão de "pastor-cura" para uma de "pastor-testemunha-servo". No proêmio emerge logo a continuidade com o Vaticano I (citado em todo o tratado 9 vezes entre documentos e atos conciliares) e logo emerge a continuidade e o valor inalienável do ministério petrino para se crer firmemente, porque "princípio e fundamento perpétuo e visível da unidade da fé e da comunhão".

\section{A sacramentalidade do episcopado}

Da estrutura acima apresentada emerge também a relação paralela entre a sacramentalidade do episcopado e sua dimensão colegial com o proprium de todo ministério episcopal expresso através de três ofícios. O núcleo do tratado é o fundamento da sacramentalidade do episcopado, precisamente a apostolicidade. Como nota o grande teólogo do concílio Congar: 
O episcopado e o apostolado têm isto em comum, que respondem a uma missão e se referem a uma condição ao mesmo tempo de presença e de ausência: devem um e outro tornar presente o Senhor ausente. [...] é um vicariato [um fazer as "vezes"] o exercício de uma mesma autoridade, uma mesma ação, uma mesma missão, mas ad opera de outras pessoas [...] Os apóstolos foram por isto escolhidos, consagrados e enviados pelo Senhor mesmo. Os bispos o são através de uma mediação. [...] Depois do desaparecimento dos apóstolos, os bispos realizaram uma presença do ministério apostólicos -e, com isto, do Senhor mesmo- à frente da comunidade, no lugar dos apóstolos já ausentes [...] não é estranho que a partir do fim do IV século, primeiramente no Oriente, depois em Roma e na Gália, a imposição do livro dos evangelhos sobre o novo eleito expresse o sentido profundo da consagração de um bispo. ${ }^{4}$

Nesta perspectiva teológica se compreende o significado de "sucessores" dos apóstolos, compreendido em sentido não pessoal/individual, mas colegial, cada bispo sucede em uma sedes episcopal o colégio apostólico. Sinal desta dimensão colegial é o fato de que para a ordenação episcopal eram necessários ao menos três bispos das igrejas vizinhas, como já atestava a Traditio Apostolica na liturgia da ordenação e depois confirmada por Niceia ${ }^{5}$ Destas tradições antiquíssimas, compreendemos como a natureza do episcopado é colegial e como suas origens remontam à tradição dos apóstolos e seu precípuo ministério. Não por acaso, para explicar a sacramentalidade do episcopado, a LG 21 afirma: "na pessoa dos Bispos, assistidos pelos presbíteros, está presente no meio dos fiéis o Senhor Jesus Cristo, pontífice máximo. Sentado à direita de Deus Pai, não deixa de estar presente ao corpo dos seus pontífices". ${ }^{6}$ Nesta continuidade histórica entre Cristo e os bispos encontramos a via "genética e vertical" que o Concílio segue ao apresentar os fundamentos do episcopado ${ }^{7}$ e pretende explicar a fonte mesma do ministério episcopal na sagrada ordenação. Primeiramente, é retomada a recuperação da natureza sacramental do episcopado que encontra sua fonte na sagrada ordenação, e, por consequência, compreendemos melhor também o conceito de "sucessão" e o justo valor que o concílio atribui ao termo.

\footnotetext{
${ }^{4}$ Id., La Chiesa è Apostolica, p. 654-655.

${ }^{5}$ Cf. PIÉ-NINOT, S. Ecclesiologia, p. 394-396, com ampla bibliografia.

${ }^{6}$ Lumen Gentium 21; EV 1/334.

${ }^{7}$ Cf. LÉCUYER, J. "L 'Episcopato come Sacramento", in BARAÚNA, G. (ed.), La Chiesa del Vaticano II. Studi e commenti intorno ala Costituzione dommatica Lumen Gentium, Firenze: Vallecchi, 1965, p. 713-732; aqui: 713-715.
} 
Uma breve, mas necessária, premissa de caráter histórico é retomada. Com a Reforma gregoriana do século XI e o subsequente nascimento da ciência canônica no século XII, assistiu-se a um deslocamento da compreensão da Igreja da dimensão primariamente sacramental -uma eclesiologia eucarística que encontra sua fundamentação em Inácio de Antioquia - para uma realidade social, uma corporação de tipo jurídico onde os sacramentos são "gestos" segundo normas precisas. Neste período, há a passagem ou melhor a inversão dos termos para designar a eucaristia e a Igreja: enquanto antes a eucaristia era definida como o corpo "místico ou misterioso" de Cristo e a Igreja como o "corpo verdadeiro" de Cristo, nesta fração histórica acontece a inversão. Isto leva a distinguir as duas realidades (sacramental e jurídica) da Igreja, confiando a primeira ao presbítero - o qual detém o "poder sacramental ou de ordem" sobre o corpo de Cristo, isto é, a eucaristia - enquanto ao bispo corresponde o "poder jurídico" sobre o corpo místico de Cristo, a Igreja. Assim, a teologia medieval, retomando Jerônimo (Epístola 146), a começar por Pedro Lombardo faz emergir uma distinção entre episcopado e presbiterado não mais de tipo sacramental, mas jurídico. Isto motiva o fato de que os reformados, exceto em poucos casos, só conservaram o episcopado, com função prevalentemente administrativo-jurídica. As consequências ocorreram também sobre o papado: torna-se, como diz Agostinho Triunfo (+ 1328) "o nome da jurisdição". ${ }^{8}$ Esta cisão entre sacramentalidade e jurisdição levará também as ordenações episcopais "absolutas", ou seja, aquelas dos bispos "titulares", onde a visão de Igreja em chave jurídica vê no episcopado um organismo administrativo que vai além ou acima das igrejas particulares, portanto, uma colegialidade que precede a própria sinodalidade das igrejas. Não estamos exprimindo um juízo de valor, mas de fato, captamos a concepção do proprium do episcopado assim como emerge no segundo milênio, ao ponto que o CJC de 1917 can. 981 afirma a distinção entre bispos com título de "missão", ou seja, os bispos titulares e aqueles com título de "serviço às dioceses". Se quisermos, "a apostolicidade" é própria das testemunhas oculares que não foram em sentido estrito "bispos de uma igreja local específica", mas fundadores da igreja no seu complexo; portanto, o seu era um encargo único e irrepetível. A questão hoje é objeto de discussão em âmbito teológico e ecumênico e pode oferecer diversos motivos de reflexão.

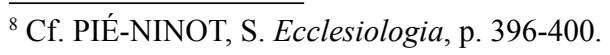


Na vigília do Concílio, durante o pontificado de Pio XII, aparece a velha questão sobre o valor da ordenação: se de tipo sacramental ou só como solene colocação jurídica. A dupla visão foi objeto de tensão também no seio do concílio, prova é a promulgação da Nota explicativa prévia à Lumen Gentium que pretende dar uma interpretação correta do capítulo III.

O texto fundamental sobre a sacramentalidade do episcopado é a LG 21 onde se afirma que Cristo ensina, santifica e governa por meio dos bispos. Isto não exclui outra ministerialidade, mas estes são canais preferenciais e primários da ação de Cristo Chefe e Pastor. Estas ações que Cristo cumpre retomam a consequencialidade apresentada na conclusão de Materus. O primado é dado à pregação, depois a administração dos sacramentos da fé com a inserção no corpo eclesial, e dirigir e ordenar o povo, testemunhando o Evangelho. Liga-se tudo isto à efusão especial do Espirito Santo, seja à tarde da Páscoa, segundo Jo 20, 22-23, seja a Pentecostes (At 1,8; 2,4), que na Igreja se perpetua no episcopado. Portanto, na Nota explicativa se afirma que na ordenação episcopal a causa ontológica é dada pelo rito mesmo de consagração (imposição das mãos e oração de consagração com a imposição do livro dos Evangelhos), enquanto a condição para o exercício de tal ministério é dada pela canonica determinatio, ou seja, pela missio canonica, da eleição e da comunhão com o papa e com o colégio. Reza o parágrafo dois da Nota: "Um vem constituído membro do colégio em virtude da consagração episcopal e mediante a comunhão hierárquica com o chefe do colégio e com os membros"; nisto se retoma literalmente a LG 22 (EV 1/336).

Na sagração é conferida a participação ontológica nos ofícios sagrados, como indubitàvelmente consta da Tradição, mesmo litúrgica. Intencionalmente se emprega a palavra munerum e não potestatum, porque esta última palavra poderia entender-se como poder apto para o exercício. Ora, para que tal poder exista, deve sobrevir a determinação canónica ou jurídica, por parte da autoridade hierárquica. Esta determinação do poder pode consistir na concessão de um ofício particular ou na atribuição de súbditos. ${ }^{9}$

Em substância, o concílio afirma que se é bispo só depois da consagração episcopal e se pode exercer autenticamente e livremente tal ministério com a condição de estar em comunhão com todo o colégio e seu chefe, o papa. A jurisdição não é um poder propriamente dito, mas um ato mediante o qual a

${ }^{9} L G$, Nota esplicativa: $E V$ 1/450. 
autoridade legitima o campo de exercício de poderes preexistentes ou recebidos de outro modo, ou seja, através da ordenação. Retomando assim um pensamento já consolidado em Santo Tomás, pode-se dizer que com a ordenação (até o concílio se preferia o termo "consagração", no mesmo sentido usado para a eucaristia, mas a reforma litúrgica preferirá o termo "ordenação") todo ato realizado por um bispo validamente ordenado é válido, mas é ilícito se for realizado não seguindo as normas da Igreja. ${ }^{10}$

Como todo sacramento também o episcopado se caracteriza por uma graça específica e dá o caráter sacramental peculiar da ordem. Se a matéria do sacramento é a imposição das mãos e a forma é a oração consecratória - que, desde antiquíssima tradição é acompanhada pela imposição dos Evangelhos, como sinal do altíssimo valor consacratório, que faz um servo e testemunha da Palavra - a graça conferida é a plenitude da sagrada ordem, e o caráter configura o ordenando com Cristo, chefe, mestre, pastor e sacerdote, agindo por sua vez na Igreja.

\section{A dimensão colegial do episcopado}

O concílio nos oferece uma segunda nota peculiar sobre o episcopado: a dimensão colegial. Esta realidade equilibra a teologia pós-Vaticano I que acentuara a plenitudo potestatis romana em prejuízo dos bispos, não obstante as retomadas de valor como o texto da Conferência episcopal alemã de von Bismarck em 1875. ${ }^{11}$

Um dos estudiosos mais profundos sobre a colegialidade foi J. Ratzinger. Em um de seus numerosos estudos, aquele clássico sobre a interpretação do De Ecclesia do Vaticano II, retoma a história e a problemática do conceito de "colégio" depois da reforma, concebido por alguns segundo uma visão igualitária da Igreja com prejuízo da visão hierárquica. Ele sublinha como no texto preparado pela comissão teológica em 1962 encontramos uma diferença substancial a respeito daquele conclusivo de 1964, enquanto a ideia mesma de colegialidade estava inicialmente ligada só à relação com a sede apostólica de Roma; não tinha nenhuma retomada nítida da dimensão sacramental. Afirma o jovem Ratzinger:

Quanto à referência ao pertencimento do colégio dos bispos, o esquema

${ }^{10}$ Cf. LÉCUYER, J. L`Episcopato come Sacramento, 722-727.

${ }^{11} \mathrm{Cf}$. Denzinger-Hünermann 3112. 
de 1962 declarava que, sui jure, eram membros deste colégio os bispos residenciais que viviam em paz com a sede apostólica. Assim, a única e verdadeira raiz da colegialidade aparecia como sendo a jurisdição episcopal sobre uma determinada diocese. Portanto, a colegialidade estava completamente destacada da realidade sacramental e transferida ao plano da realidade jurídica; pois que na atual práxis da Igreja latina a jurisdição é, de fato, entregue ao bispo pelo papa; naturalmente a conclusão a considerar, em definitivo, é que o colégio dos bispos era pura criação do direito pontifício e assim se dissolveria novamente a grande ideia, antes de chegar a pensá-la até ao fundo. ${ }^{12}$

Isto motiva o fato de que LG 22 retoma a dupla raiz do episcopado: a sagrada ordenação e a comunhão hierárquica com o papa e com os outros bispos. Por tal motivo, na sede do concílio se introduz este argumento em LG 19, onde se retoma o primado "vocacional" do ministério episcopal, assim como afirmado em Mc 3, 13-19; chamou aqueles que Ele quis, isto é, os Doze, para que ficassem com ele e para enviá-los a pregar. Os polos da ação dos bispos são estar com o Senhor e a missão, mas a fonte é o chamado e a constituição em forma de colégio o coetus/grupo estável no qual o chefe era Pedro, escolhido entre eles. ${ }^{13}$ Não se considere de modo superficial a dimensão missionária do episcopado porque é participação autêntica e sacramental da apostolicidade da Igreja. Tal dimensão foi reforçada também no diretório para o ministério dos bispos de 2004, Apostolorum Sucessores nn. 7-12.

O acréscimo de "coetus" por parte da comissão teológica do concílio e a referência a Pedro são devidas - diz o papa teólogo - às pressões provenientes, sobretudo, do mundo curial e do grupo dos italianos; assim se pretende usar também termos afins como "ordo", "corpus", termos encontráveis na tradição da Igreja primitiva. A superação de uma visão individualística do ministério, uma espécie de isolamento a favor de uma dimensão comunitária, na lógica da corresponsabilidade, da conspiratio in unum, da sollicitudo universa $1^{14}$ que todo bispo deve sentir e viver enquanto responsável firmemente da Igreja, abre uma visão comunal que é típica da teologia do Vaticano II, confirmada

\footnotetext{
${ }^{12}$ RAZTINGER, J. "La collegialità episcopale: spiegazione teologica del testo conciliare in BARAÚNA, G. (ed.), La Chiesa del Vaticano II, o.c., p. 738. O mesmo texto foi publicado em colaboração com K. Rahner in Episcopato e Primato, Brescia: Morcelliana, 1966 e republicado em 2007 depois da eleição papal. Tudo isto é encontrável na Opera Omnia, vol. 8.

${ }^{13}$ Cf. Ibidem, 733-736.

${ }^{14} L G 23: E V 1 / 339$.
} 
pelo Sínodo de 1985. "Não se pode nunca ter comunhão só com o papa, mas estar em comunhão com ele significa necessariamente ser "católico", ou seja, estar igualmente em relação de comunhão com todos os outros bispos, que pertencem à "Católica". ${ }^{15}$ Fundamentar a colegialidade ao nível sacramental não mais considerando como realidade de direito eclesiástico ligada ao papa, mas de direito divino, e devolver ao bispo sua autêntica missão de ser centrum unitatis na sua Igreja local e instrumentum communionis na relação entre as Igrejas e na Igreja Católica no seu conjunto, permite significar o valor mesmo da ministerialidade na Igreja que brota do sacramento e se pode exercer como justamente a tradição patrística sempre sustentou - na forma comunal/ colegial. Relevante é também a feliz expressão de Cipriano: "episcopatus unus est, cuiús a singulis in solidum pars tenetur", ${ }^{16}$ onde se acentua a unidade do episcopado e a participação do indivíduo naquela unidade indissolúvel que diz a natureza colegial que a caracteriza.

Esta dimensão colegial retoma necessariamente a natureza mesma do colégio apostólico, que é aplicada e transferida para a realidade do colégio episcopal, ainda que com as devidas diferenças. Em LG 22, consideram-se paralelamente a relação Pedro e os outros apóstolos e o papa e os outros bispos. Tal paralelismo é expresso por uma expressão "pari ratione" e não "cadem ratione", como originariamente fora proposto pela comissão preparatória. Por quê? Que coisa isto quer dizer? A Nota prévia explica bem, evidenciando o proprium dos apóstolos que não é transmitido e um poder transmitido aos sucessores, que efetivamente podemos chamar de "vigários dos apóstolos"; enquanto possuem uma potestas é sempre reenvio àquela dos apóstolos.

Colégio não se entende em sentido jurídico estrito, ou seja, de um grupo de iguais, que delegam o seu poder ao que preside; mas no sentido de um grupo estável, cuja estrutura e autoridade se devem deduzir da Revelação. [...] O paralelismo entre Pedro e os restantes Apóstolos por um lado, e o Sumo Pontífice e os Bispos pelo outro, não implica a transmissão do poder extraordinário dos Apóstolos aos seus sucessores, nem, como é evidente, a igualdade entre a Cabeça e os membros do Colégio, mas apenas uma proporcionalidade entre a primeira relação (Pedro-Apóstolos) e a segunda (Papa-Bispos). Daí ter a Comissão resolvido escrever no inicio do n. ${ }^{\circ} 22$ «pari ratione» e não « eadem ratione». ${ }^{17}$ [ não mesmo, mas de modo semelhante]

\footnotetext{
${ }^{15}$ RATZINGER, J. La collegialità episcopale, 738-739.

${ }^{16}$ CIPRIANO DI CARTAGINE, De Ecclesiae Catholicae unitate, 5: PL 4, 516.

${ }^{17} L G$, Nota explicativa: $E V 1 / 448$.
} 
Existe uma unicidade do apostolado que não é transmissível e se refere a toda a Igreja; e os bispos não são apóstolos, nem mesmo o papa é o apóstolo Pedro em senso estrito (talvez só "simbolicamente" assim se diz); também se para ele existe uma sucessão pessoal e não colegial para o ligame com a sede romana, testemunha do ministério e do martírio de Pedro. A diferença entre o papa e os bispos não repousa na relação diversa com o ofício dos apóstolos, mas na assunção de um ministério de modo diferente: o Papa tem referência a Pedro e seu ministério é para a Igreja universal em senso estrito, e o bispo sucede no colégio episcopal a todo o colégio dos apóstolos em uma sede específica que no limitar determina (canonica determinatio) a peculiaridade de seu ministério, que tem sempre uma solicitude pela totalidade/universalidade (a portio Populi Dei pro toto) enquanto membro de um colégio episcopal e expressão de uma Igreja particular. Os dois elementos (colégio e igrejas locais) não estão cindidos; caso contrário, existiria o risco, ou da visão "funcional" do colégio, separado das igrejas reais ( contudo, todos os bispos, também os titulares, não podem não ter uma sede de referência; não se é bispo sem uma igreja já desde Nicéia I), ou da visão "autocéfala", típica do mundo oriental, onde toda igreja corre o risco de ser autônoma e independente das outras, porque se retém autossuficiente em si mesma.

A unidade e a pluralidade são os polos da comunhão católica que o colégio em si encarna e exprime. As duas visões teológicas da colegialidade que emergem são aquela universalística do colégio, qual órgão que gere a Igreja Universal junto ao papa, onde a dimensão local é diminuída; ou uma colegialidade que parta das Igrejas locais na unidade da Igreja Universal, onde esta perspectiva mais sinodal favorece - segundo quanto já a tradição patrística revela - um diferente gradualismo nas relações entre os bispos antes ao nível regional/nacional e depois mais universal para as questões mais importantes. Esta última visão corresponde ao critério enucleado por um antigo princípio, retomado por Congar: quod omnes tangit ab omnibus tractari debet..$^{18}$ Isto garante também certa autonomia ao episcopado que não "dependeria in toto de Roma", mas quer dizer: retomar o princípio de "subsidiariedade" e do papa como princípio e fundamento da comunhão eclesial, garantia da autenticidade da fé, mas não o super-bispo do qual os outros dependam. Isto abre amplo debate sobre o papel das conferências episcopais, os sínodos regionais ou nacionais, e o papel das novas formas de colegialidade sobre as quais

${ }^{18}$ Cf. CONGAR.Y. M. In: Rev. hist. droit. franc. et étr. 36 (1958), 210-259. 
hoje estão refletindo. Papa Francisco na Evangelii Gaudium 32 retoma estes mesmos aspectos.

\section{Os três múnus do bispo}

O Concílio tem sua originalidade não negligenciável ao ler o ministério episcopal à luz das tria munera. Na realidade trata-se de um triplex munus, como revela também a exortação pós sinodal de João Paulo II sobre o ministério dos bispos, Pastores Gregis 9: "o bispo quando ensina, ao mesmo tempo santifica e governa o Povo de Deus; enquanto santifica, também ensina e governa, quando governa, ensina e santifica". Também a Christus Dominus no capítulo II, parte I (CD 11-18) trata de modo abundante e sistemático destes três ofícios explicitados em vários modos com uma riqueza de dados muito interessantes. Existe, pois, uma realidade composta no ministério episcopal que é devidamente considerada. Antes do concílio, pensava-se que o poder sagrado provinha da consagração episcopal, enquanto o poder do governo e o do magistério eram unidos, no poder de jurisdição, que comportava o poder do bispo de impor a "verdadeira doutrina" aos seus súditos, juntamente aos fiéis, que só com o Vaticano II recuperam a plena dignidade enquanto "povo de Deus".

Além disso, o concílio aplica a tríade de Cristo sacerdote, profeta e rei não só aos bispos, mas também aos presbíteros ( $\mathrm{PO} 4-6)$, aos diáconos (LG 29) e aos leigos (LG 34-36). Nisto retoma quanto a Mystici Corporis (17 e 108: EV 6/166; 256) tinha afirmado, retomando Calvino, mas aplicando à Igreja. O Sínodo de 2001 tinha como tema: " O Bispo, servidor do Evangelho de Jesus Cristo para a esperança do mundo"; e teve entre os relatores o então card. Bergoglio e como secretário Dom Semerato. Tudo isto é muito significativo! Na sua introdução João Paulo II, no parágrafo 5 afirma:

É o Cristo mesmo que repete aos Sucessores daqueles Apóstolos, que este convite ouviram de sua viva voz, e, confiando Nele, partiram para a missão nas estradas do mundo: Duc in altum (Lc 5, 4). À luz deste insistente convite do Senhor, "nós podemos reler o tríplice munus confiado à Igreja: munus docendi, sanctificandi et regendi. Duc in docendo!" Anuncia a palavra - diremos com o Apóstolo -, insiste em toda ocasião, oportuna e inoportunamente, admoesta, corrige, exorta com toda magnanimidade a doutrina $(2 \mathrm{Tm} 4,2)$. Duc in sanctificando! As redes que somos chamados a lançar entre os homens são antes de tudo os Sacramentos, dos quais somos os principais dispensadores, reguladores, guardiães e promotores. 
Esses formam uma espécie de rede salvífica, que liberta do mal e conduz à plenitude da vida. Duc in regendo! Como Pastores e verdadeiros Pais, ajudados pelos Sacerdotes e outros colaboradores, temos a tarefa de congregar a família dos fiéis e nela fomentar a caridade e a comunhão fraterna. Porquanto se trata de uma missão árdua e fatigosa, ninguém perca o ânimo. Com Pedro e com os primeiros discípulos também nós renovamos confiantes a nossa sincera profissão de fé: Senhor, "na tua palavra jogarei as redes" (Lc 5, 5)! Na tua palavra, ó Cristo, queremos servir ao teu Evangelho para a esperança do mundo!" (Homilia pronunciada no início da X Assembleia Geral Ordinária do Sínodo dos Bispos, em 30. 9. 2001).

Os três ofícios juntam-se como a chave de retorno à hermenêutica do Vaticano II e da teologia do episcopado. De fato, a exortação apostólica como também o Diretório Apostolorum Successores de 2004 retomam estas três dimensões como realidade fundante na estruturação mesma e na nucleação da teologia do ministério episcopal.

Possamos, pois, colher três aspectos salientes de quanto foi dito: a dimensão diaconal do ministério episcopal. LG 24 destaca: "Este encargo que o Senhor confiou aos pastores do Seu povo é um verdadeiro serviço, significativamente chamado "diaconia" ou ministério na Sagrada Escritura (cfr. Act. 1, 17 e 25; 21-19; Rom. 11, 13; 1 Tim. 1,12)" ${ }^{19}$ Esta dimensão é marcadamente desejada e sublinhada por Congar em seus estudos, já durante os anos do concílio para acentuar os fundamentos teológicos de um ministério que devia resguardar-se de formalidade e de hierática a favor de uma lógica mais evangélica e extrovertida da Igreja e de seus pastores. ${ }^{20}$ Tal visão do episcopado marca decididamente também o valor mesmo da interpretação e da compreensão dos três ofícios do bispo. Este deve olhar antes de tudo para sua santificação pessoal, que se realiza concretamente naquela caridade pastoral para animar seu ser e agir em uma lógica de "pro-existência": um ser para/a favor dos outros. Não por acaso, o ofício de reger, o "governo" da Igreja é posto no terceiro lugar, querendo remarcar a dimensão primariamente "ministerial" da vida do bispo. O concílio mesmo impôs maior sobriedade dos bispos no vestuário - não mais hábitos principescos, nem títulos muitas vezes ainda nobiliárquicos- na linguagem ou estilo muito afinado à lógica do mundo e não

\footnotetext{
${ }^{19} L G 24: E V 1 / 342$.

${ }^{20}$ CONGAR, Y. M.- DUPUY, R. D. (edd.), L episcopato e la Chiesa universale. Roa: Paoline, 1965, 87-166. São dois artigos publicados na original francês em 1962.
} 
conforme ao ideal evangélico. Um fundamento bíblico é reencontrável no dia santíssimo da instituição do sacerdócio, quando recordamos o despojamento do Senhor a usar como único e verdadeiro paramento o avental, e, como único báculo a jarra e a bacia para lavar os pés. Como dizia um santo bispo de Pulha, do qual é já adiantada a causa de beatificação, D. Tonino Bello: estola e aventais são os símbolos da nossa vida, menos direitos de estola e mais deveres de aventais, para sermos sinal de Cristo, Evangelho vivente que não só foi posto sobre a cabeça na ordenação, mas também é modelo inspirador e farol que ilumina o caminho de cada pastor.

Uma segunda nota é aquela do ensinamento, que justamente o concílio define como "pregação" e a põe no primeiro lugar quanto às outras duas. LG 25 afirma:

Entre os principais encargos dos Bispos ocupa lugar preeminente a pregação do Evangelho (75). Os Bispos são os arautos da fé que para Deus conduzem novos discípulos. Dotados da autoridade de Cristo, são doutores autênticos, que pregam ao povo a eles confiado a fé que se deve crer e aplicar na vida prática. ${ }^{21}$

De grande valor ecumênico e bíblico o termo "pregar" (precones/ Keryches) que retoma o Kerygma. O anunciador profético deve "gritar" a Palavra, proclamá-la oficialmente; assim são "doutores" autênticos a quem os fiéis são levado a "obedecer" (em grego hypakoé, escuta em profundidade). O bispo, para exercer autenticamente seu ofício de pregação, deve viver em profunda comunhão com o papa e com os outros bispos; por isto LG 25 prolonga seu significado de magistério, sobretudo, o da infalibilidade do papa e do episcopado inteiro. Este texto foi incorporado ao da DV 10 que, ao afirmar o papel que só tem o magistério vivo da Igreja, na interpretação autêntica da Palavra de Deus, escrita e transmitida, afirma que: "este magistério, porém, não está acima da palavra de Deus, mas a serve, ensinando somente aquilo que foi transmitido, por mandato divino e, com a assistência do Espírito Santo, piedosamente escuta, santamente guarda e fielmente expõe esta palavra". ${ }^{22} \mathrm{O}$ Decreto sobre o ofício pastoral dos bispos especifica os termos deste ministério da pregação, destacando que se trata de um "dever" (CD 12), o primeiro entre os principais, individuando também o empenho "social" que desenvolvem na promoção da vida e da dignidade de todo homem.

\footnotetext{
${ }^{21} L G 25: \mathrm{EV} 1 / 344$.

${ }^{22}$ Dei Verbum 10: EV 1/887.
} 
Ensinem,por isso, quanto, segundo a doutrina da Igreja, valem a pessoa humana, com a sua liberdade e a própria vida corpórea; a família e a sua unidade e estabilidade, a procriação e a educação dos filhos; a sociedade civil, com as suas leis e profissões; o trabalho e o descanso, as artes e a técnica; a pobreza e a riqueza. Exponham, por fim, os princípios com que se hão-de resolver os problemas gravíssimos da posse, do aumento e da justa distribuição dos bens materiais, da paz e da guerra, e da convivência fraterna de todos os povos. ${ }^{23}$

Este input do concílio torna-se tanto mais profético hoje e uma provocação para a autenticidade e a séria responsabilidade no exercício deste delicado ministério. ${ }^{24}$

Uma terceira realidade que é destacada é a função de santificar, que o liga de modo inseparável à eucaristia e à sua presidência eclesial que se exprime autenticamente e plenamente na ação litúrgica. "Revestido da plenitude do sacramento da Ordem, o Bispo é o «administrador da graça do supremo sacerdócio», principalmente na Eucaristia, que ele mesmo oferece ou providencia para que seja oferecida". ${ }^{25} \mathrm{O}$ bispo é "oeconomus" da graça do sumo sacerdócio, pois a sua é uma função de guardião e dispensador da graça para ser o eixo da vida eclesial, o presidente da assembleia litúrgica, da qual SC 26 fala retomando a dimensão "epifânica" da celebração. Este tema foi desenvolvido em particular na SC 41: "convencidos de que a principal manifestação da Igreja se faz numa participação perfeita e activa de todo o Povo santo de Deus na mesma celebração litúrgica, especialmente na mesma Eucaristia, numa única oração, ao redor do único altar a que preside o Bispo rodeado pelo presbitério e pelos ministros". ${ }^{26}$ Estes textos concordam com a LG 1 onde se define a Igreja como "o sacramento, ou sinal, e o instrumento da íntima união com Deus e da unidade de todo o género

${ }^{23}$ CD 12: EV 1/ 598.

${ }^{24}$ A Pastores Gregis dedica amplo espaço a este empenho "profético" do bispo. O terceiro capítulo é intitulado "Mestre da fé e arauto da Palavra", donde se extrai uma missão evangelizadora que considera devidamente a inculturação do Evangelho; no sétimo capítulo se afronta a delicada questão do relacionamento bispo e desafios atuais, precisamente as questões de justiça e paz, o diálogo inter-religioso, os relacionamentos com o mundo da política, da economia, o empenho na salvaguarda do criado e da dignidade da pessoa e da sua vida e saúde; a atenção prioritária aos pobres e aos marginalizados, como os migrantes.

${ }^{25} L G 26: E V 1 / 348$.

${ }^{26} L G 26: E V 1 / 348$. 
humano". ${ }^{27}$ Em substância, a opus salutis que a Igreja realiza na celebração expressa plenamente seu ser mediador de salvação. A Igreja na sua natureza significa e realiza (sinal e instrumento) a comunhão Deus-homem em toda a sua vida e em todas as suas ações, mas isto se realiza especificamente na liturgia. O ofício de santificar próprio do bispo se exprime neste ministério de comunhão que deve realizar-se a partir da celebração eucarística. Além disso, aparece claro que na eucaristia atua a Igreja com suas quatro notas. De fato o texto diz: "Christi virtute consociatur", ou seja, recolhe, constitui, chama a si a comunidade. Pode-se concluir afirmando que na eucaristia presidida pelo bispo se manifesta a unidade e a pluralidade ministerial da Igreja, o cume e a fonte da comunhão eclesial. Os dípteros, ou seja, a menção do papa e do bispo na missa, são um grande sinal de comunhão que se exprime naquela celebração e que dali parte para a vida de toda a comunidade.

\section{Ao modo de conclusão}

Partindo das reflexões conciliares, podemos nuclear quatro breves aspectos conclusivos que explicitam de modo sintético quanto foi afirmado, oferecendo assim uma leitura teológica em chave eucarística do ministério episcopal, que bem se une com quanto o Concílio nos ensinou. Na realidade destaco também o valor da "presidência eclesial" que todo bispo é chamado a viver em seu ministério, o seu ser personalidade corporativa daquela portio populi Dei que ele lhe foi confiada. Em SC 26 e 41 afirma-se que a precípua manifestação da Igreja a temos na eucaristia, que, segundo a tradição tomista, tem características específicas, ${ }^{28}$ encontráveis também no ministério episcopal e em toda presidência eclesial: a dimensão memorial / pascal, a dimensão comunal / diaconal, aquela santificante / escatológica e da última, aquela testemunhal / martirológica que representa o centro unificante das outras dimensões.

Papa Francisco na Evangelii Gaudium 13 afirma que "A memória é uma dimensão da nossa fé que podemos chamar "deuteronômica", em analogia com a memória de Israel. Jesus nos deixa a Eucaristia como memória cotidiana da Igreja, que nos introduz sempre mais na Páscoa". O evento fundador e central da Páscoa (ephapax salvífico) se re-presenta nos sinais sacramentais, graças à ação do Espírito do Ressuscitado. O zikkarôn é o ato ritual (sacramental) desta

\footnotetext{
${ }^{27} L G 1: E V 1 / 284$.

${ }^{28}$ Cf. STh III, q.60, a.3c. SC 10: EV 1/17.
} 
recordação atualizadora. ${ }^{29} \mathrm{~A}$ presidência eclesial, pois, por sua natureza exige esta dimensão de "reenvio", de memória atualizadora do mistério pascal e do papel dos apóstolos.

Além disso, pode-se verificar que o termo grego episkopos retoma aquele hebraico shaqad que designa a visita de Deus, sua presença em meio ao seu povo. ${ }^{30}$ Paulo, porém, usa também o termo presbyteroi, e "parece precisamente que ele pense em uma função da atividade pastoral (cf. Ef 4,11) - em paralelo àquela de presidência (proistamenos -cf. $R$ m 12, 8; $1 \mathrm{Ts} 5,12 ; 1 \mathrm{Tm}$ $5,17)$ ou de dirigente hegoumenos - cf. $\mathrm{Hb} 13,7.17 .24)$ - mais que o nome dado a um ministério preciso". ${ }^{31} \mathrm{O}$ presbítero deve ser modelo, memória e testemunha autêntica da vida segundo o Evangelho (cf. Tt 1,6-9; 1Tm 3, 2-7; $2 \operatorname{Tm}$ 2, 24-26) e guardião (phylacson, 1Tm 6, 20; 2Tm 1, 12-14; Tt 1, 13) do depósito da fé. ${ }^{32}$ Portanto, a presidência eclesial tanto do bispo quanto de todo presbítero, para ser autêntica, deve necessariamente remeter à Páscoa de Cristo, não só no anúncio e na celebração do mistério, mas também no ser mediação, e, remeter constantemente ao essencial e não à sua pessoa e/ou ao próprio clichê celebrativo ou pastoral. Quando, porém, o leadership episcopal ou presbiteral se torna dependência ou corresponsabilidade? Às vezes parece que a passagem de uma presidência a outra diga não descontinuidade na continuidade, mas novidade absoluta, história que se inicia, esquecendo aquilo que nos precedeu. A simbólica pascal diz, pois, também purificação da experiência de mediação que quem preside deve cumprir segundo a afirmação autenticamente evangélica do Batista: “Ele deve crescer”, isto é Jesus, e "eu diminuir", porque a salvação é obra de Cristo, nunca de quem preside a comunidade.

Uma categoria teológica posterior que deduzimos da eucaristia é aquela escatológica que diz a tensão para a santidade. A categoria bíblica de memorial está estreitamente ligada à tradição hebraica do yom kyppur, que acentua uma dinâmica estreita entre o sacrifício, a purificação/expiação do povo e dos sacerdotes e a unidade e santidade de todo o povo de Deus. Tudo

${ }^{29}$ Cf. THURIAN, M. L'Eucaristia, Memoriale del Signore, Roma 1979, 41. TILLARD, J.M.R. L'Eucaristia e la Chiesa, in "Sacra Doctrina" 12 (1967), 326-328. Id., Autorité et mémoire dans l’Église, Irénikon 61 (1988), 332-346;481-484.

${ }^{30}$ Cf TILLARD. J.M.R. Volti dell'episcopato. Le figure storiche del vescovo nella Chiesa in un volume. EDB, in Regno-attualità 46 (2001), 603-609.

${ }^{31}$ Ibidem, 603.

${ }^{32}$ Cf. Ibidem. 
isto evidencia a necessidade contínua do povo de purificar-se, de converter-se, sinal da sua inadequação diante da santidade divina, mas também apresenta em uma ação sagrada (sacri-fício) a possibilidade de entregar a Deus, por sua explícita vontade e misericórdia, toda a vida. A eucaristia, pois, insere-se muito bem também neste dinamismo do "já" da comunhão com Deus e do "ainda não" de modo pleno, sendo "remédio de eternidade" para os crentes. ${ }^{33}$ O bispo "o sumo-sacerdote do seu rebanho, de quem deriva e depende, de algum modo, a vida de seus fiéis em Cristo" (SC 41) tem, como a eucaristia, a função de santificar, ou seja, de arrancar do pecado e da morte, e de introduzir na eternidade divina, finalidade própria de toda a Igreja (cf. LG V). A caridade pastoral que deve animar o pastor deve ter como única meta aquela de facilitar ao máximo o caminho de santificação dos fiéis. A ars celebrandi do presbítero ou do bispo deve facilitar todo crente a experimentar o espaço salvífico que se entrelaça na sua história. Põe-se, pois, a velha questão da pregação (cf. Evangelii Gaudium 135-175) e da santidade de vida.

Existe um terceiro aspecto típico da eucaristia: ela é convívio, comunhão. $\mathrm{O}$ verdadeiro munus regendi é um serviço à comunidade. De fato, ao presidir os sagrados mistérios na quinta-feira santa, o dia soleníssimo dedicado ao sacerdócio e à eucaristia, reevoca-se o despojamento de Cristo e seu fazer-se de servo ao lavar os pés. Presidir é servir, nãocomandar, como diz Jesus em Lc 22, 24-30; toda eucaristia deve retomar este princípio: quem preside é o chefe da comunidade e não a pode dominar como único ator da cena ou um titereiro, mas exprime na pluralidade de ministérios a unidade da Igreja, o convergir para o unum que é Cristo Senhor. Quem preside deve "significar" a eucaristia celebrada na atenção autêntica aos pequenos, aos sofredores e aos doentes, às pessoas que de vários modos vivem a dificuldade com pleno espírito das bem-aventuranças evangélicas. ${ }^{34}$

Não por último em importância, a eucaristia diz também a dimensão martirológica: toda a eucaristia é um apelo constante ao testemunho do vivido. No contexto de profundo intimismo religioso, isto aparece como a grande provocação para todo crente, e in primis para o presidente. $\mathrm{O}$ apelo a viver a eucaristia na vida concreta torna-se a urgente manifestação da Igreja no mundo, enquanto experiência sanadora e de graça da liturgia a ser fermento

${ }^{33}$ IGNAZIO DI ANTIOCHIA, Lettera gli Effesini, 20,2: SChr.10bis, 76.

${ }^{34}$ Cf. Id., Il n`est d’Église qu`eucharistique, Nicolaus 10 (1982), 233-262. O teólogo canadense colhe a relação estreita entre a realidade eclesial e o ministério de presidência do bispo e o relevo dado ao batismo e à concorporatio no mistério da unidade (237-239). 
de vida nova no mundo. Esta dimensão "social" da eucaristia encontra na presidência eclesial um dos aspectos mais salientados, sem o qual não há ligame com o lugar, contexto sociológico e histórico do realizar-se na Igreja. ${ }^{35}$ Portanto, a visão "extrovertida" da Igreja no seu ser missionário revela que toda presidência não é só "in-vocativa", um interceder por e com os fiéis para introduzir Deus na sua história, mas também "e-vocativa", isto é, conduz os fiéis já empenhados para aqueles que estão longe (dimensão apostólica da Igreja), para fazê-los sair de seus "jardins fechados" para o diálogo que se faz partilha, partilha que faz amizade, amizade que se torna experiência de Deus peregrino na história. Esta missionariedade hoje deve assumir sempre mais os traços do "martírio" num contexto frequentemente adverso ou indiferente em relação ao cristianismo onde já estamos nos tornando minoria.

Portanto, retomando quanto Agostinho dizia de si e de seu ministério, pode-se concluir, afirmando: "praepositi sumus et servi sumus; praesumus sed si prosumus" (somos presidentes e servos e presidimos se servimos). ${ }^{36} \mathrm{Se}$ para o bispo a catedral é o símbolo da esponsalidade e do serviço que o liga à sua Igreja, e é a memória viva da fé da comunidade local, o sacramento da diaconia que o une à Igreja, pode-se dizer que toda presidência autenticamente eclesial não pode prescindir daquela presidência litúrgica onde a dinâmica esponsal Cristo-Igreja e ministro-comunidade e a mediação "pascal" do presidente assumem os traços autênticos de Cristo esposo, mestre, servo e testemunha.

\section{Referências bibliográficas}

AGOSTINO. Sermo Guelferbytanus 32, I: Miscellanea Agostiniana I, 564-565 CIPRIANO DI CARTAGINE. De Ecclesiae Catholicae unitate, 5: PL 4, 516. CONGAR, Y.M. "La Chiesa è Apostolica”. In Mysterium Salutis VII, Brescia: Queriniana, 1972.

CONGAR, Y. M. La collégialité épiscopale, Paris: Cerf, 1963.

CONCÍLIO VATICANO II. Lumen Gentium 21.

CONGAR, Y.M. L'Episcopat e l’Eglise universelle. Paris: Cerf, 1962.

\footnotetext{
${ }^{35}$ Cf. NIGRO, F. Presidenza eucarística presidenza ecclesiale, Fides et Ratio 4 (2/2011), 247-268.

${ }^{36}$ AGOSTINO, Sermo Guelferbytanus 32, I: Miscellanea Agostiniana I, 564-565.
} 
CONGAR.Y. M. In: Rev. hist. droit. franc. et étr. 36 (1958), 210-259.

CONGAR, Y. M.- DUPUY, R. D. (ed.). L'episcopato e la Chiesa universale. Roa: Paoline, 1965, 87-166.

CONCÍLIO VATICANO II. Christus Dominus.

CONCÍLIO VATICANO II. Dei Verbum.

CONCÍLIO VATICANO II. Lumen Gentium.

CONCÍLIO VATICANO II. Sacrosanctum Concilium.

IGNAZIO DI ANTIOCHIA. Lettera gli Effesini, 20,2: SChr.10bis, 76.

KASPER, W. Chiesa Cattolica. Essenza - Realtà - Missione. BTC 157, Brescia: Queriniana, 2012, 369ss.

LÉCUYER, J. "L`Episcopato come Sacramento". In: BARAÚNA, G. (ed.). La Chiesa del Vaticano II. Studi e commenti intorno ala Costituzione dommatica Lumen Gentium, Firenze: Vallecchi, 1965.

NIGRO, F. Presidenza eucarística presidenza ecclesiale. Fides et Ratio 4 (2/2011), $247-268$.

PIÉ-NINOT, S. Ecclesiologia. La sacramentalità della comunità Cristiana. BTC 138, Brescia: Queriniana, 2008.

RAZTINGER, J. "La collegialità episcopale: spiegazione teologica del testo conciliare. In: BARAÚNA, G. (ed.). La Chiesa del Vaticano II. Studi e commenti intorno ala Costituzione dommatica Lumen Gentium, Firenze: Vallecchi, 1965.

THURIAN, M. L'Eucaristia, Memoriale del Signore, Roma 1979.

TILLARD, J.M.R. Autorité et mémoire dans 1'Église, Irénikon 61 (1988), 332-346;481-484.

TILLARD, J.M.R. 1'Église locale. Ecclésiologie de communion et catholicité, Paris 1995, 160-196.

TILLARD, J.M.R. L'Eucaristia e la Chiesa, in "Sacra Doctrina” 12 (1967), 326-328. 
TILLARD. J.M.R. Volti dell'episcopato. Le figure storiche del vescovo nella Chiesa in un volume. EDB, in Regno-attualità 46 (2001), 603-609.

PASCASIO RADBERTO. In Mattheo II, 3: PL 120, 168.

TOMÁS DE AQUINO. Suma Theologica III, q.60, a.3c. SC 10: EV 1/17.

Dom Filippo Santoro

Doutor em Teologia pela Pontificia Università Gregoriana (Roma) Consultor do Pontifício Conselho para os Leigos Taranto - Itália E-mail: segretariavescovo@taranto.chiesacatolica.it

Recebido em: 17/10/14 Aprovado em: 20/10/14 